\title{
Introducing the IDEF0 Methodology in the Strategic Planning of Projects for Reclamation and Repurposing of Surface Mines ${ }^{\dagger}$
}

\author{
Philip-Mark Spanidis ${ }^{1}$, Francis Pavloudakis ${ }^{2}$ and Christos Roumpos ${ }^{2, *(D)}$ \\ 1 ASPROFOS Engineering, Division of Project Management, 17675 Athens, Greece; pspani@asprofos.gr \\ 2 Public Power Corporation of Greece, Mining Engineering Department, 10432 Athens, Greece; \\ f.pavloudakis@dei.com.gr \\ * Correspondence: c.roumpos@dei.com.gr; Tel.: +30-210-5109500 \\ + Presented at International Conference on Raw Materials and Circular Economy, Athens, Greece, \\ 5-9 September 2021.
}

\begin{abstract}
The closure of surface mines is a complex framework characterized by extended reclamations of post-mining sites towards an environmentally friendly and sustainable land-use system development with beneficial returns to society and the economy. The paper demonstrates the critical mine closure problem, draws research questions, and introduces the IDEF0 (Integrated DEFinition Function) process modelling method as a low-cost and easy development tool for use by mining experts to perform strategic planning of sustainable mine reclamation and repurposing projects. A case study for the method applied in a Greek lignite mine is presented.
\end{abstract}

Keywords: IDEF0; mines; process; reclamation; strategic planning; sustainability

check for

updates

Citation: Spanidis, P.-M.;

Pavloudakis, F.; Roumpos, C.

Introducing the IDEF0 Methodology in the Strategic Planning of Projects

for Reclamation and Repurposing of

Surface Mines. Mater. Proc. 2021, 5, 26. https://doi.org/10.3390/materproc 2021005026

Academic Editor: Evangelos Tzamos

Published: 23 November 2021

Publisher's Note: MDPI stays neutral with regard to jurisdictional claims in published maps and institutional affiliations.

Copyright: (C) 2021 by the authors. Licensee MDPI, Basel, Switzerland. This article is an open access article distributed under the terms and conditions of the Creative Commons Attribution (CC BY) license (https:/ / creativecommons.org/licenses/by/ $4.0 /)$.

\section{Introduction}

Surface mines are complex, long term and large-scale excavation sites of high significance for raw and critical materials supply and primary energy production. Over time, mining operations generate various impacts on the environment and society [1-3]. Once a mine enters the closure phase, several strategic questions and decisions related to the sustainable transformation of mined sites are coming into the front. In this context, developing an adequately organized and well-functioning framework for the mined lands repurposing constitutes an issue of crucial strategic importance [4]. The objective of this paper is: (a) to present the fundamental problems of the mine-closure phase and address research questions and (b) to advise a strategic planning methodology appropriate for the mine transformation from the viewpoint of sustainability and circular economy. The contribution of this research is to show how the IDEF0 method, which is broadly applied in systems engineering and business process modelling, can be successfully transferred as a low-cost and easy development tool appropriate for situational analysis and strategic planning of post-mining initiations.

\section{Mine Closure: Problems and Research Questions}

The closure phase is part of a mine's operation lifecycle that may last for many years $[5,6]$. When a mine enters the ageing/closure phase, several categories of problems concerning the sustainable transformation of the mined lands are coming into front [4]. These problems address scientifically substantial analysis and cost-effective planning to ensure that the actions to sustainability will be environmentally friendly and socio-economically robust. The first category of problems relates to the cumulative geoenvironmental impacts caused by the poor quality, in terms of fertility and mechanical properties, and heterogeneity of excavated soils, the contaminated/toxic water that flows in the final mine pit, the effects in landscape and modification of landforms, etc. Economic and social impacts are an equally important category of problems since people working 
in mine earthworks, logistics, services, etc. may understand the closure and transition of a mine to sustainability as a potential livelihood threat. Furthermore, the circular econ-

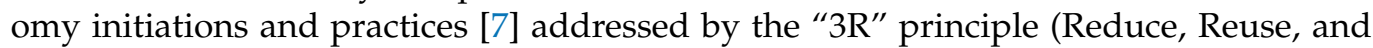
Recycle) may generate opposition from stakeholders' sides. These practices could be related to the reuse of dumped rocks, aggregates or other by-products as raw material for backfilling, recycling, etc. [4]. As such, these activities might be seen as a source of new environmental impacts.

In recent years, many countries pay much attention and make a significant effort to introduce the practices of circular economy in the mining industry [4] with an aim to (a) mitigate the environmental impacts generated by the long term and intensive mining activity, much earlier than mines formally enter the ageing/closing phase, (b) build-up the basis for the sustainable management of post-mining soils and waste materials and (c) train and consult society to start thinking about the business opportunities of circular economy as regards the heavily impacted mine sites. In this frame, the Extractive Waste Management Plans (EWMP) is, for example, a guidance document of the European Commission focused on best practices for circularity and encouraging the sustainability initiations and new business viewpoints in the extractive industry [8].

The above assumes that the post-mining repurposing initiations and frameworks require effective strategic planning adjusted to the technical, geo-environmental and social characteristics of the mines under concern. The strategic planning should set up the basis of a repurposing/reclamation project execution $[1,3,9,10]$, through which the postexploitation landscape, landforms, residual materials and land uses can be effectively (re)engineered and improved, in parallel to the adoption by the local communities of a new, financially robust and sustainable model of economic development. However, the transformation to sustainability draws critical research questions with practical essence on how, why, and to which extent the strategic planning of a mine repurposing/reclamation could be performed. In particular: (a) How can the strategic planning be analyzed and structured from the viewpoint of a business model consisting of specific functional entities? (b) Which are the fundamental strategic processes by which a repurposing/reclamation project can be structured as a functional business entity? (c) Is there any tool(s)/method(s) suitable for modelling, design, and implementation of post-mining strategic planning frameworks? (d) Can strategic planning be used as a background for a cost-effective and socio-environmentally appropriate repurposing/reclamation project? In the framework of these questions, the authors suggest that the post-mining strategic planning be further investigated as a multidisciplinary business entity consisting of specific processes and implemented as a properly organized and managed project, maintaining its scope, resources, and time-plan.

\section{Materials and Methods}

\subsection{The IDEFO Process Modelling Method}

In the theory and practice of project management, strategic planning is crucial for the successful organization, development, and execution of any project. A viable project strategy plays an essential role for the: (a) understanding of a project as an entity with specific technical and business content aiming at certain ends and performed using specific means [11,12]; (b) project communication to stakeholders and (c) decision making on techno-economic issues of high social and environmental impact. Furthermore, since post-mining projects are complex frameworks, strategic planning addresses requirements for a more profound investigation of the business functions, the so-called processes, by which this type of project can be executed. The method that suits better the project strategic planning requirements is IDEF0, a process modelling technique and industrial standard as well, with extended literature references in the analysis and design of projects in the fields of manufacturing, aerospace, business, and information systems science and technology [13,14]. 
The acronym IDEF0 stems from the Integrated DEFinition Function and modelling technique. IDEF0 was initially developed in the mid-1970s and the late 1980s adopted by the US AirForce as an Integrated Computer-Aided Manufacturing (ICAM) initiative [15]. In 1993, IDEF0 was validated as an IEEE standard, part of ISO standards [16]. Furthermore, literature shows that IDEF0 has extendedly developed as a systems engineering tool. Examples of systems designed by the IDEF0 technique are a process model developed for the geo-metallurgical flowsheet visualization [17]; a structured methodology for the enterprise modelling in UK organizations [15]; a model for the needs of the construction industry [18]; a computer-aided simulation developed for the design and deployment of a knowledge management system [19]; an application model for the analysis of social, economic, technical and environmental components of energy systems [20]. Also, a substantial review of the IDEF0 contribution in industrial systems' strategic management, planning and automation are provided in [21].

IDEF0 is an engineering workflow structuring and modelling technique combining graphics and text entities. IDEF0 syntax represents [16] the hierarchy of process models in a structured and systematic way using: (a) box diagrams to define processes or activities, (b) arrows to represent the data flows, interlinks, and feedback loops among processes, and (c) entities every single process requires for its activation, enabling the integrated composition of processes in a model: Inputs and Outputs (data or objects), Mechanisms (e.g., materials, resources, knowledge, and/or other means), and Controls (decisions, legislative or regulatory constraints, contracts, time plans). These entities are known by the acronym ICOM [22]. IDEF0 is a top-bottom task ontology showing the level of analysis each process is dealing with, where the top event (or parent) diagram (A-0 or "A minus zero" element) represents the primary process of the system to be further analyzed. Under this event, the constituent processes are merged at a lower, more detailed level of analysis. In turn, the constituent processes can become parental events of process merged at a lower level of analysis and so on.

\subsection{Case Study: An IDEFO Post-Mining Strategic Model}

A case study of IDEF0 development in the strategic modelling for a closing lignite mine in Greece is presented. The steps of the suggested methodology are S1-Understanding and defining the context of Strategic Planning; S2-Select the IDEF0 process modelling method as appropriate; S3-Outline the Concept diagram (A-0) "Post-Mining Restoration/Repurposing Strategic Planning"; S4-Decompose the Strategic Planning into sub-processes to the level of detail required (Table 1); S5-Identify the ICOM entities (Table 2) and communication lines (arrows); S6-Compose, Design and Validate the IDEF0 model; S7-Develop the Strategic Planning and Project Execution context. The outlined IDEF0 model consists of four (4) sub-processes identified as children functions of the top event A-0. The sub-processes are A1-"Setting up the Strategic Context"; A2-"Perform the mine Situational Analysis"; A3"Evaluate and Select the Reclamation/Repurposing Strategy"; A4-"Develop the Restoration Project Execution Plan". In Figure 1, the A-0 concept diagram is presented schematically, and in Figure 2, the top-bottom decomposition of A-0 into sub-processes and the IDEF0 process model mapping are described, along with the ICOM entities and interlinking arrows reflecting the overall structure and functionality. 
Table 1. Description of Processes / Activities.

\begin{tabular}{|c|c|c|c|}
\hline \multicolumn{4}{|c|}{ A-0: Strategic Planning for a Reclamation/Repurposing Project (top event) } \\
\hline \multicolumn{4}{|c|}{ Sub-Process-ID: A1-Setting-up the Strategic context } \\
\hline $\mathrm{A}(1.1)$ & Analysis of Sustainability policies & $\mathrm{A}(1.6)$ & Analysis of Strengths and Weaknesses \\
\hline $\mathrm{A}(1.2)$ & Consideration of environmental impacts & $\mathrm{A}(1.7)$ & Scope pre-screening \\
\hline $\mathrm{A}(1.3)$ & Consideration of socio-economic impacts & $\mathrm{A}(1.8)$ & Preliminary time planning \\
\hline $\mathrm{A}(1.4)$ & Investigation of Reclamation/Repurposing technologies & $\mathrm{A}(1.9)$ & $\begin{array}{l}\text { Budgetary estimation of alternative } \\
\text { Reclamation/Repurposing scenarios }\end{array}$ \\
\hline $\mathrm{A}(1.5)$ & First round of Stakeholders Engagement & $\mathrm{A}(1.10)$ & Outlining the concept of Strategy(ies) \\
\hline \multicolumn{4}{|c|}{ Sub-Process-ID: A2-Geo-Environmental Data Collection $\mathcal{E}$ Situational Analysis } \\
\hline $\mathrm{A}(2.1)$ & Preparation of site layouts for the landscape and landforms & $\mathrm{A}(2.7)$ & $\begin{array}{l}\text { Sampling of contaminated/polluted receptors } \\
\text { (soil-waters-air) }\end{array}$ \\
\hline $\mathrm{A}(2.2)$ & Analysis of mine's waste management records/procedures & $\mathrm{A}(2.8)$ & Impact analysis and mitigation measures \\
\hline $\mathrm{A}(2.3)$ & Analysis of Satellite Imagery and Remote Sensing data & $\mathrm{A}(2.9)$ & $\begin{array}{l}\text { Review of previous mine development plans and } \\
\text { risk assessments }\end{array}$ \\
\hline $\mathrm{A}(2.4)$ & Analysis of biotic, non-biotic and ecological factors & $\mathrm{A}(2.10)$ & $\begin{array}{l}\text { Considering the legislative constraints and } \\
\text { development programs }\end{array}$ \\
\hline $\mathrm{A}(2.5)$ & $\begin{array}{l}\text { Analysis of socio-economic factors, land use and } \\
\text { infrastructures }\end{array}$ & $\mathrm{A}(2.11)$ & $\begin{array}{l}\text { Evaluating the mining material and space } \\
\text { suitability for } 3 R \text { initiatives }\end{array}$ \\
\hline $\mathrm{A}(2.6)$ & Geological, geotechnical and geophysical investigation & $\mathrm{A}(2.12)$ & Second round of Stakeholders Engagement \\
\hline \multicolumn{4}{|c|}{ Sub-Process-ID: A3-Selection of the Reclamation/Repurposing Strategy } \\
\hline $\mathrm{A}(3.1)$ & Identification of the alternative Strategies & $\mathrm{A}(3.6)$ & Finalizing the Cost Analysis (for each strategy) \\
\hline $\mathrm{A}(3.2)$ & $\begin{array}{l}\text { Submission of the Reclamation/Repurposing Plan to } \\
\text { Stakeholders }\end{array}$ & $\mathrm{A}(3.7)$ & Finalizing the Feasibility assessment \\
\hline $\mathrm{A}(3.3)$ & Public Consultation & $\mathrm{A}(3.8)$ & $\begin{array}{l}\text { Selection of Strategy (Multi-Criteria Decision } \\
\text { Making-MCDM method) }\end{array}$ \\
\hline $\begin{array}{l}\mathrm{A}(3.4) \\
\mathrm{A}(3.5)\end{array}$ & $\begin{array}{l}\text { Consideration of Stakeholders' / Authorities' feedback } \\
\text { Filling the gaps and reformulating the strategies }\end{array}$ & $\mathrm{A}(3.9)$ & Approval of the selected Strategy \\
\hline \multicolumn{4}{|c|}{ Sub-Process-ID: A4-Performing the Project Execution Plan } \\
\hline $\mathrm{A}(4.1)$ & $\begin{array}{l}\text { Developing the Project and Construction Management } \\
\text { systems }\end{array}$ & $\mathrm{A}(4.4)$ & Work and Cost breakdown analysis \\
\hline $\mathrm{A}(4.2)$ & Preparation of Tendering & $\mathrm{A}(4.5)$ & $\begin{array}{l}\text { Setup the Quality, Risk and HSSE Management } \\
\text { systems }\end{array}$ \\
\hline \multirow[t]{2}{*}{$\mathrm{A}(4.3)$} & Organization and Planning of the project & $\mathrm{A}(4.6)$ & $\begin{array}{l}\text { Setup Environmental Monitoring and } \\
\text { Management }\end{array}$ \\
\hline & & $\mathrm{A}(4.7)$ & $\begin{array}{l}\text { Request for Proposal (RfP) and Bidders } \\
\text { evaluation }\end{array}$ \\
\hline
\end{tabular}

Table 2. ICOM Entities: Inputs, Controls, Outputs, Mechanisms.

\begin{tabular}{|c|c|c|c|c|}
\hline \multirow{2}{*}{ Description of Entities } & \multicolumn{4}{|c|}{ Processes } \\
\hline & A1 & A2 & A3 & A4 \\
\hline Mine Decommissioning Plan & $\mathrm{I}(1.1)$ & $\mathrm{C}(2.1)$ & $\mathrm{C}(3.1)$ & $\mathrm{C}(4.1)$ \\
\hline Policies/Regulations for the Sustainable development \& Circular Economy & $\mathrm{I}(1.2)$ & & $C(3.2)$ & $C(4.2)$ \\
\hline Mine Company Corporate \& Social Responsibility & $\mathrm{I}(1.3)$ & & & \\
\hline Mine Operation and Field inspection archives & $\mathrm{I}(1.4)$ & & & \\
\hline Lessons Learned & $\mathrm{I}(1.5)$ & $\mathrm{I}(2.3)$ & $\mathrm{I}(3.3)$ & $\mathrm{O}(4.4)$ \\
\hline Pre-feasibility assessment & $\mathrm{O}(1.1)$ & $\mathrm{I}(2.1)$ & & \\
\hline Reclamation Planning and Timeline & $\mathrm{O}(1.2)$ & $\mathrm{C}(2.2)$ & $\mathrm{C}(3.3)$ & $\mathrm{C}(4.3)$ \\
\hline Preliminary Cost Estimation (CAPEX \& OPEX) & $\mathrm{O}(1.3)$ & $\mathrm{C}(2.3)$ & $C(3.4)$ & \\
\hline Risk and Natural Hazards assessment & $\mathrm{O}(1.4)$ & & & $\mathrm{C}(4.4)$ \\
\hline Stakeholders feedback (Authorities, Municipalities, NGOs, etc.) & $\mathrm{O}(1.5)$ & & $\mathrm{M}(3.3)$ & \\
\hline Standards for Quality, HSSE and Risk management & $\mathrm{M}(1.1)$ & $\mathrm{M}(2.1)$ & & $\mathrm{M}(4.1)$ \\
\hline Policies/Instruments of International Finance Corporations (IFC) & $\mathrm{M}(1.2)$ & & & \\
\hline Business and Financial analysis tools (SWOT, BCA, NPV/IRR, etc.) & $\mathrm{M}(1.3)$ & & & \\
\hline
\end{tabular}


Table 2. Cont.

\begin{tabular}{|c|c|c|c|c|}
\hline \multirow{2}{*}{ Description of Entities } & \multicolumn{4}{|c|}{ Processes } \\
\hline & A1 & A2 & A3 & A4 \\
\hline Legislation for occupational health \& safety & & $\mathrm{C}(2.4)$ & & $\mathrm{C}(4.5)$ \\
\hline Satellite Imagery and Remote Sensing data & & $\mathrm{I}(2.2)$ & & \\
\hline Situational analysis of the mine & & $\mathrm{O}(2.1)$ & & \\
\hline Environmental \& Social Impacts Assessment (ESIA) & & $\mathrm{O}(2.2)$ & $\mathrm{I}(3.1)$ & \\
\hline Mine landscape and landforms upgrading plan & & $\mathrm{O}(2.3)$ & & $\mathrm{I}(4.1)$ \\
\hline Feasibility study (final) & & $\mathrm{O}(2.4)$ & $\mathrm{I}(3.2)$ & $\mathrm{I}(4.2)$ \\
\hline Engineering studies (specifications, technical reports, area layouts, etc.) & & $\mathrm{O}(2.5)$ & & $\mathrm{I}(4.3)$ \\
\hline Design Codes, Standards and best practices of mining industry & & $\mathrm{M}(2.2)$ & & $\mathrm{M}(4.2)$ \\
\hline Public Consultation Minutes of Meeting (MOMs)/ protocols & & & $\mathrm{O}(3.1)$ & \\
\hline Reclamation/Repurposing Strategy (selected) & & & $\mathrm{O}(3.2)$ & $\mathrm{I}(4.4)$ \\
\hline Expert teams (managers, engineers, ecologists, financial analysts, etc.) & $\mathrm{M}(1.4)$ & $\mathrm{M}(2.3)$ & $\mathrm{M}(3.1)$ & \\
\hline Decision Making software tools (for AHP, TOPSIS or other methods) & & & $\mathrm{M}(3.2)$ & \\
\hline Project Development and Execution plan & & & & $\mathrm{O}(4.1)$ \\
\hline Tender packages & & & & $\mathrm{O}(4.2)$ \\
\hline Detailed Cost Analysis & & & & $\mathrm{O}(4.3)$ \\
\hline Project \& Risk management tools (MS-Project, @Risk, etc.) & $\mathrm{M}(1.5)$ & & & $\mathrm{M}(4.3)$ \\
\hline Environmental \& Social Impacts mitigation measures/plans (ESIA content) & & & & $\mathrm{M}(4.4)$ \\
\hline
\end{tabular}

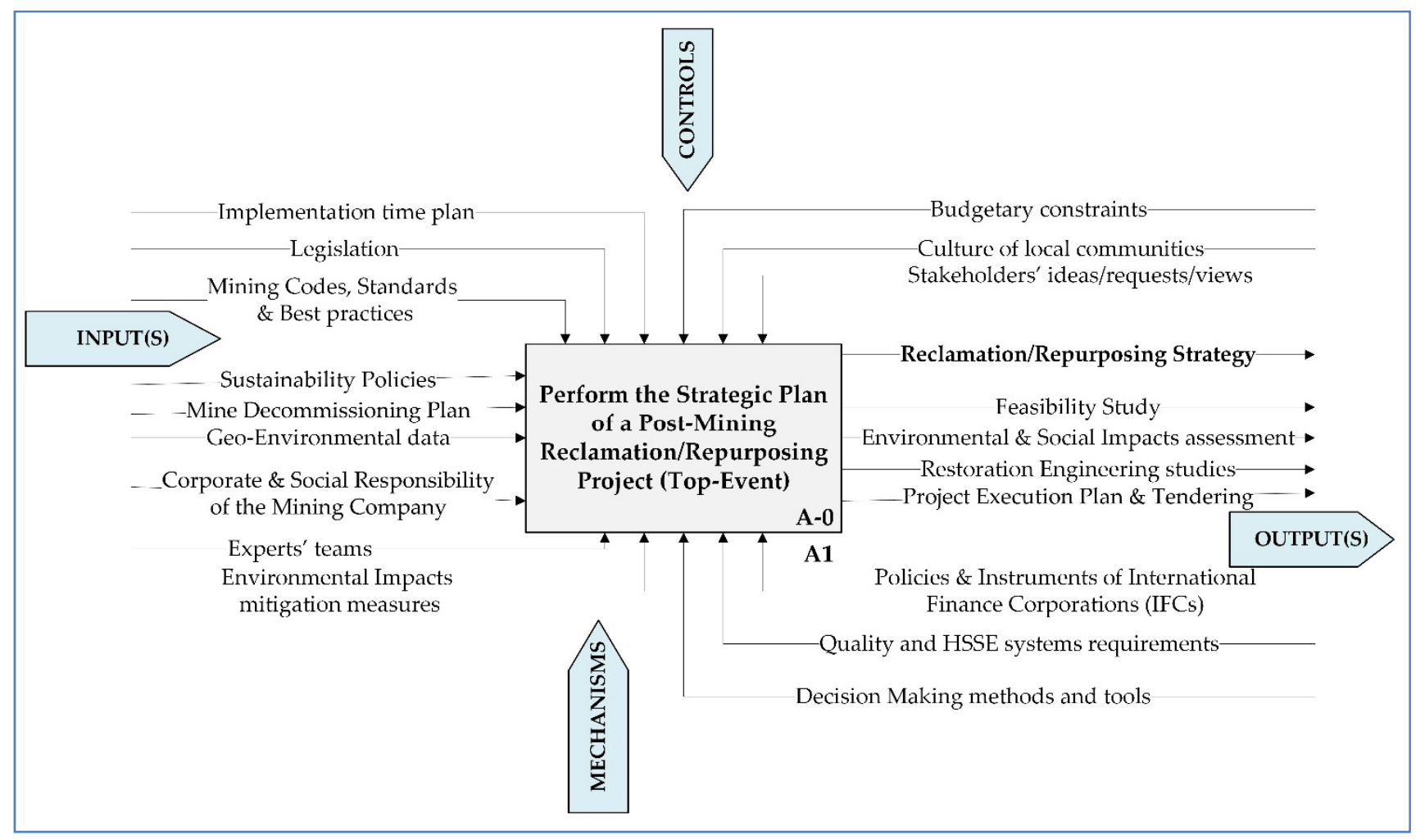

Figure 1. The A-0 concept diagram "Post-Mining Restoration/Repurposing Strategic Planning". 


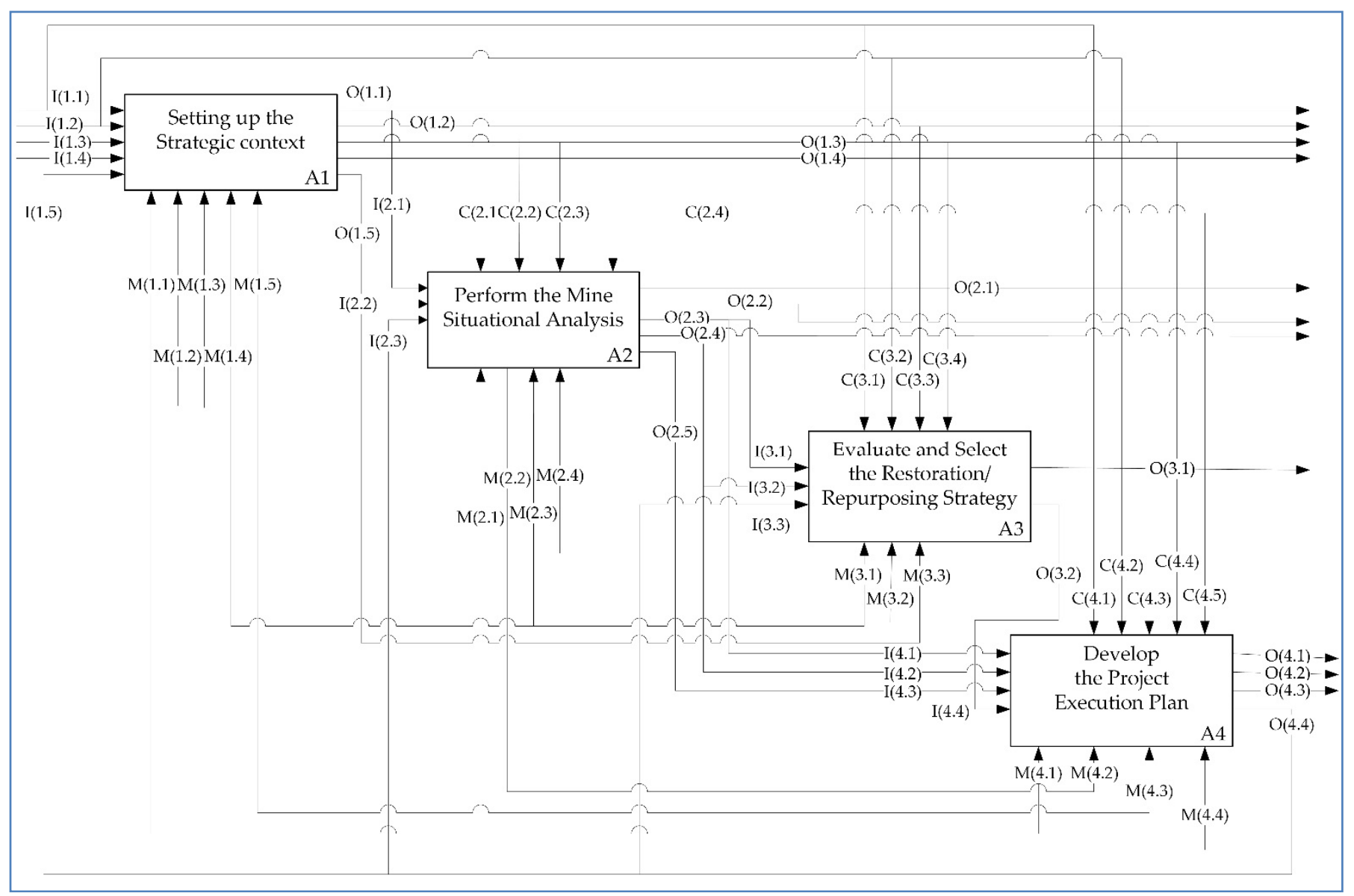

Figure 2. Top-bottom decomposition of A-0 into sub-processes and IDEF0 process model mapping, along with the ICOM entities.

\subsection{Analysis and Validation of Sub-Processes}

The conducted analysis shows that each sub-process maintains its content and purpose in the systemic representation and workflow of the "Strategic Planning" business process model consisting of certain structural and functional elements.

Sub-process A1 consists of activities the mining company performs in order to understand the sustainability policies, define alternative strategic plans, analyze the overall socioeconomic impacts and mitigation/recovery measures, pre-screen the stakeholders' expectations, and prepare the techno-economic assessments by which a reclamation/repurposing project can be proven a financially and socio-environmentally feasible business entity, along with a SWOT (strengths, weaknesses, opportunities and threats) analysis of a mine's transition to sustainability. Sub-process A2 provides a consistent engineering judgement and elaboration of the design studies aligned to the interventions and infrastructures each feasible strategy addresses in case of a post-mining sustainability system development based on 3R (and/or other) circular economy policies. Each strategy's impacts and mitigation measures/policies are consistently evaluated in an integrated environmental and social impacts assessment. Sub-process A3 deals with a participatory decision-making process by which the most promising strategy is evaluated and selected with the contribution of mining experts, stakeholders, and authorities, using group decision techniques like Analytical Hierarchy Process (AHP) or others [23-25]. Finally, sub-process A4 refers to the establishment of a project management system by which the post-mining sustainability framework can be executed according to the financial, quality, safety and performance principles set based on social and corporate responsibility policies of the mining company and the regulatory, environmental, and social compliance constraints and requirements set by authorities and stakeholders. 
The IDEF0 model was validated in two (2) semi-structured meetings with the participation of experts with different professional duties and origins (mining managers, sociologists, environmentalists, engineers, public officials, representatives of municipalities). In the first meeting, a pre-screening of critical strategic purposes, the sustainability perspectives and relevant alignments were discussed, while in the second meeting, the proposed IDEF0 model was thoroughly reviewed, and corrective/improving suggestions were incorporated.

\section{Discussion and Conclusions}

The transition of surface mines to sustainability is a complex and long-term project, requiring effort and effective strategy supported by the mining company and stakeholders with authority to make critical strategic decisions. In investigations of post-mining strategies, IDEF0 constitutes a practical and creating value managerial tool adequate for explicitly identifying, designing, and modelling sustainable strategy functions. Furthermore, IDEF0 can be easily applied using software such as MS-Visio and SmartDraw. As a method, it requires short development time for the identification, multidisciplinary analysis and (re)composition of the business process model clearly and straightforwardly. Moreover, IDEF0 validation is participatory, interactive, and less complicated work.

Nevertheless, IDEF0 presents some disadvantages: it is static and fits better to the current situation of a mine operation, but, over time, the initially designed business process model addresses reengineering and improving reconsiderations. Also, IDEF0 does not allow quantitative analysis of the business case/entity under concern, although some processes it reflects might be quantitative in their entity, such as the multi-criteria selection of the sustainable strategies shown in the case study. Finally, the number of the hierarchical levels to which the analysis can be extended is crucial: if these levels are more than three, difficulties in the visualization capability and validation of the method might be generated. Thus, the experience of IDEF0 analyst(s) and the mining experts' judgement and knowledge in the business process model formulation are indispensable.

In conclusion, IDEF0 constitutes a helpful and low-cost tool usable in shaping the strategic concept of mine transformation projects. However, as further research, the combination of IDEF0 with other IDEF family methods, like IDEF3, to enforce the purpose of strategic decision making should be interesting. Also, combining IDEF0 task ontology with knowledge management and process analysis methods focused on sustainability in the mining industry might be challenging and interesting.

Author Contributions: Conceptualization, P.-M.S., C.R. and F.P.; methodology, P.-M.S., F.P. and C.R.; software, P.-M.S., F.P. and C.R.; validation, P.-M.S., F.P. and C.R.; formal analysis, P.-M.S., F.P. and C.R.; investigation, P.-M.S., F.P. and C.R.; data curation, P.-M.S., F.P. and C.R.; writing-original draft preparation, P.-M.S.; writing-review and editing, P.-M.S., F.P. and C.R.; visualization P.-M.S., F.P. and C.R.; supervision P.-M.S., F.P. and C.R.; project administration, P.-M.S., F.P. and C.R. All authors have read and agreed to the published version of the manuscript.

Funding: This research received no external funding.

Institutional Review Board Statement: Not applicable.

Informed Consent Statement: Not applicable.

Data Availability Statement: The data presented in this study are available upon request from the corresponding author.

Conflicts of Interest: The authors declare no conflict of interest. 


\section{References}

1. Chuman, T. Restoration Practices used on Post mining Sites and Industrial Deposits in the Czech Republic with an Example of Natural Restoration of Granodiorite Quarries and Spoil Heaps. J. Landsc. Ecol. 2015, 8, 29-46. [CrossRef]

2. Pavloudakis, F.; Roumpos, C.; Karlopoulos, E.; Koukouzas, N. Planning and implementing surface mines reclamation works under the new EU strategy for the transition of lignite intensive regions to a post-mining era. In Proceedings of the 12th International Conference of Mine Closure, Leipzig, Germany, 3-7 September 2018; pp. 139-146.

3. Spanidis, P.M.; Roumpos, C.; Pavloudakis, F. A Multi-Criteria Methodology for Low-Risk Evaluation of Mine Closure Resto-ration in Continuous Surface Lignite Mining Projects. In Proceedings of the 14th Intl. Symposium of Continuous Surface Mining (ISCSM), Thessaloniki, Greece, 23-26 September 2018; pp. 563-578.

4. Pavloudakis, F.; Roumpos, C.; Spanidis, P.-M. Optimisation of surface mining operation based on a circular economy model. In Circular Economy and Sustainability; Elsevier Publications: Amsterdam, The Netherlands, 2021; article in press.

5. McCullough, C.D. Key. Mine Closure Lessons to Be Learned; Australian Centre for Geomechanics: Perth, Australia, 2016; pp. 319-332, ISBN 978-0-99248810-4-9.

6. Stacey, J.; Naude, A.; Hermanus, M.; Frankel, P. The socio-economic aspects of mine closure and sustainable development: Literature overview and lessons for the socio-economic aspects of closure-Report-1. J. S. Afr. Inst. Mining Metallurgy 2010, 110, 379-394.

7. Zhao, Y.; Zang, L.; Li, Z.; Qin, J. Discussion on the Model of Mining Circular Economy. Energy Procedia 2012, 16, 438-443. [CrossRef]

8. European Commission (EC). Development of a guidance document on best practices in the Extractive Waste Management Plans-Circular Economy Action; Eco Efficiency Consulting and Engineering Ltd. in collaboration with WEFalck, Pöyry Finland Oy, Botond Kertész \& CRS Ingenería; European Commission: Brussels, Belgium, 2019; p. 46.

9. Prach, K.; Hobbs, R.J. Spontaneous succession versus technical reclamation in the restoration of disturbed sites. Restor. Ecol. 2008, 16, 363-366. [CrossRef]

10. Roumpos, C.; Pavloudakis, F.; Galetakis, M. Modelling and evaluation of open-pit lignite mines exploitation strategy. In Proceedings of the 2nd International Conference on Sustainable Development Indicators in the Mineral Industry (SDIMI 2005), Aachen, Germany, 18-20 May 2005; pp. 1127-1139.

11. Nickols, F. Strategy, Strategic Management, Strategic Planning and Strategic Thinking. DISTANCE CONSULTING LLC. 2011. Available online: https://nickols.us/ \{\}nickols1/strategy_etc.pdf (accessed on 2 April 2021).

12. Artto, K.; Kujala, J.; Perttu, D.; Martinsuo, M. What is a Project Strategy? Int. J. Proj. Manag. 2001, 26, 4-12. [CrossRef]

13. Lundgren, B.; Bjork, B.-C. A model integrating the facilities management process with the building end user's business processes (ProFacil). Nordic J. Surveying Real Estate Res. 2004, 1/2, 190-204.

14. Erasmus, J.; Vanderfeesten, I.; Traganos, K.; Grefen, P. Using business process models for the specification of manufacturing operations. Comp. Ind. 2020, 123, 1-21. [CrossRef]

15. Kassem, M.; Dawood, N.; Mitchell, D. A Structured Methodology for Enterprise Modelling: A case study for Modelling the Operation of a British Organization. J. Inf. Technol. Constr. 2011, 16, 381-410.

16. ISO/TR 9007. Information Processing Systems-Concepts and Terminology for the Conceptual Schema and the Information Base; International Organization for Standardizations (ISO): Geneve, Switzerland, 1987.

17. Lang, A.-M.; Ellefmo, S.-L.; Aasly, K. Geo-metallurgical Flowsheet as a tool for designing and communicating the GeoMetallurgical Programs. Minerals 2018, 8, 372. [CrossRef]

18. Akinsola, A.; Dawood, N.; Hobbs, B. Construction Planning Process Improvement Using Information Technology Tools; paper w782000-40.content; Construction Informatics Digital Library: Reykjavik, Iceland, 2000; ISSN 2706-6568.

19. Jeong, K.-Y.; Wu, L.; Hong, J.-D. IDEF method simulation model design and development. J. Ind. Eng. Man. $2009,2,337-359$.

20. Toba, A.-L.; Seck, M. Modelling Social, Economic, Technical and Environmental components in an Energy system. Procedia Comput. Sci. 2016, 95, 400-407. [CrossRef]

21. Waissi, G.; Demir, M.; Humble, J.; Lev, B. Automation Strategy using IDEF0-A proof of concept. Op. Res. Perspect. 2015, 2, 106-113. [CrossRef]

22. Kusiak, A.; Larson, N. System Reliability and Risk Assessment: A Quantitative extension of IDEF Methodologies. AAAI Technical Report SS-94-04. 1994. Available online: www.aaai.org (accessed on 5 April 2021).

23. Saaty, T.L. The Analytic Hierarchy Process; McGraw Hill International: New York, NY, USA, 1980.

24. Saaty, T.L. Decision making with the Analytic Hierarchy Process. Int. J. Serv. Sci. 2008, 1, 83-98. [CrossRef]

25. Velasquez, M.; Hester, P.T. An Analysis of Multi-Criteria Decision Making Methods. Int. J. Oper. Res. 2013, 10, 56-66. 